\title{
10. PLIOCENE AND QUATERNARY BENTHIC FORAMINIFERS FROM SITE 910, YERMAK PLATEAU ${ }^{1}$
}

\author{
Lisa E. Osterman ${ }^{2}$
}

\begin{abstract}
The benthic foraminiferal record of Ocean Drilling Program (ODP) Site 910 can be divided into four assemblage zones, from oldest to youngest: the Cassidulina spp. zone, the Elphidium spp. zone, the Elphidium albiumbilicatum zone and the Elphidium excavata forma clavata zone. The Pliocene benthic foraminifers in the three lower zones of Site 910C, 102.8-504.7 meters below sea floor (mbsf), indicate warm conditions that cool progressively from 2.7 to $1.6 \mathrm{Ma}$. Based on the number and diversity of planktonic foraminifers and the high benthic foraminiferal abundances, the lowermost Cassidulina spp. zone indicates the warmest water conditions within the Pliocene at this locality. The Elphidium spp. zone of Site 910C indicates warm but cooling conditions with decreasing foraminiferal diversities and abundances, which end with the initiation of glacial dropstones at $208.7 \mathrm{mbsf}$. The presence of species described from Pacific deposits in both lower zones suggests a Pacific Ocean influence during the late Pliocene at this site. However, climatic conditions change when Atlantic species begin to dominate the uppermost Pliocene sediments. The uppermost Pliocene sediments of the E. albiumbilicatum zone indicate glacial-marine conditions with warm episodes.

The uppermost $E$. excavatum f. clavata zone (0-102.8 mbsf), of Quaternary age, records glacial and interglacial climatic fluctuations, including one or more instances of grounded glacial ice (or episodes of severe ice-rafting) and ice-free interglacial deposits.

It appears to be possible to correlate the Pliocene benthic foraminiferal assemblages in Hole 910C with the isolated pockets of Arctic Pliocene sediment that have been previously described (Brouwers et al., 1991; Brigham-Grette and Carter, 1992; Feyling-Hanssen, 1990; Feyling-Hanssen et al., 1982).
\end{abstract}

\section{INTRODUCTION}

Ocean Drilling Program Site 910 was cored to provide a high resolution Late Neogene record of the interaction between the North Atlantic and the Arctic Oceans; it is the shallowest site in a transect along the Yermak Plateau. Approximately $504.7 \mathrm{~m}$ of nearly homogeneous silty clays were recovered at this site. This site provides an excellent record of calcareous benthic foraminifers from the longest continuous record of pre-glacial Pliocene sediment in the Arctic.

Because of eustatic and glacio-eustatic sea level fluctuations, numerous outcrops of shallow-water Pliocene marine deposits occur throughout the Arctic (e.g., Brouwers et al., 1991; Brigham-Grette and Carter, 1992; Feyling-Hanssen, 1976, 1980, 1990; Feyling-Hanssen et al., 1982, Funder et al., 1985; Todd, 1957; Vincent et al., 1984). Most of these sections indicate that the Pliocene was an interval of increased temperatures, compared to today, which has a direct bearing on the climatic history and ice cover of the Arctic Ocean. The problems with these terrestrial sites are threefold. First, most of these Pliocene sections lack any definitive age control. They are correlated either by the use of amino-acid racemization values, or by macro- or microfaunal assemblages. Second, the calcareous marine biota (benthic foraminifers, ostracodes, and molluscs) found in these shallow marine sections are strongly controlled by local environmental conditions and can be subject to loss by post-depositional dissolution (e.g., Feyling-Hanssen, 1976). Third, most of the Arctic terrestrial localities represent isolated sections of the Pliocene, which may or may not be correlative events throughout the entire Arctic.

'Thiede, J., Myhre, A.M., Firth, J.V., Johnson, G.L., and Ruddiman, W.F. (Eds.), 1996. Proc. ODP, Sci. Results, 151: College Station, TX (Ocean Drilling Program).

${ }^{2}$ Department of Paleobiology, NHB-121, Smithsonian Institution, Washington, D.C. 20560, U.S.A. osterman.1@simnh.si.edu
Hole $910 \mathrm{C}$ is the first continuous upper Pliocene marine section in the Arctic that is dated by calcareous nannofossils and planktonic foraminifers. Therefore, Site 910 should help to resolve some of the confusion that exists among the widely scattered and discontinuous Arctic Pliocene records. This paper will discuss the Pliocene and Pleistocene benthic foraminifer record of Hole 910C.

\section{MODERN OCEANOGRAPHY}

ODP Hole $910 \mathrm{C}$ is located in $556.4 \mathrm{~m}$ of water on the Yermak Plateau, northwest Svalbard continental shelf $\left(80^{\circ} 15.896^{\prime} \mathrm{N}\right.$, $\left.6^{\circ} 35.430^{\prime} \mathrm{E}\right)$, in a hydrographically unstable area of the North Atlantic-Arctic Gateway (Fig. 1). This site is located in the zone of mixing between the northward-flowing, relatively warmer West Spitsbergen Current and the colder, lower-salinity, southward-flowing waters of the East Greenland Current (Aagaard et al., 1985). The Yermak Plateau is also located at the edge of the Arctic pack ice and is covered by sea ice for most of the year, although it may have open water in late summer and early autumn during some years. Site 910 was chosen to study the interaction between water masses and climatic history within the North Atlantic-Arctic Gateway.

\section{METHODS}

Sediment in 20- $\mathrm{cm}^{3}$ samples was disaggregated with the use of a vibrating hot plate, without the use of any chemicals. Samples were soaked overnight and then mechanically agitated for up to $1 \mathrm{hr}$ before washing over a $63-\mu \mathrm{m}$ sieve. Samples were dried overnight in an oven at less than $60^{\circ} \mathrm{C}$. Samples from Hole $910 \mathrm{C}$ were picked at $>63$ $\mu \mathrm{m}$. Samples were split to obtain between 100 to 300 benthic foraminifers. If fewer foraminifers were present the sample was usually 


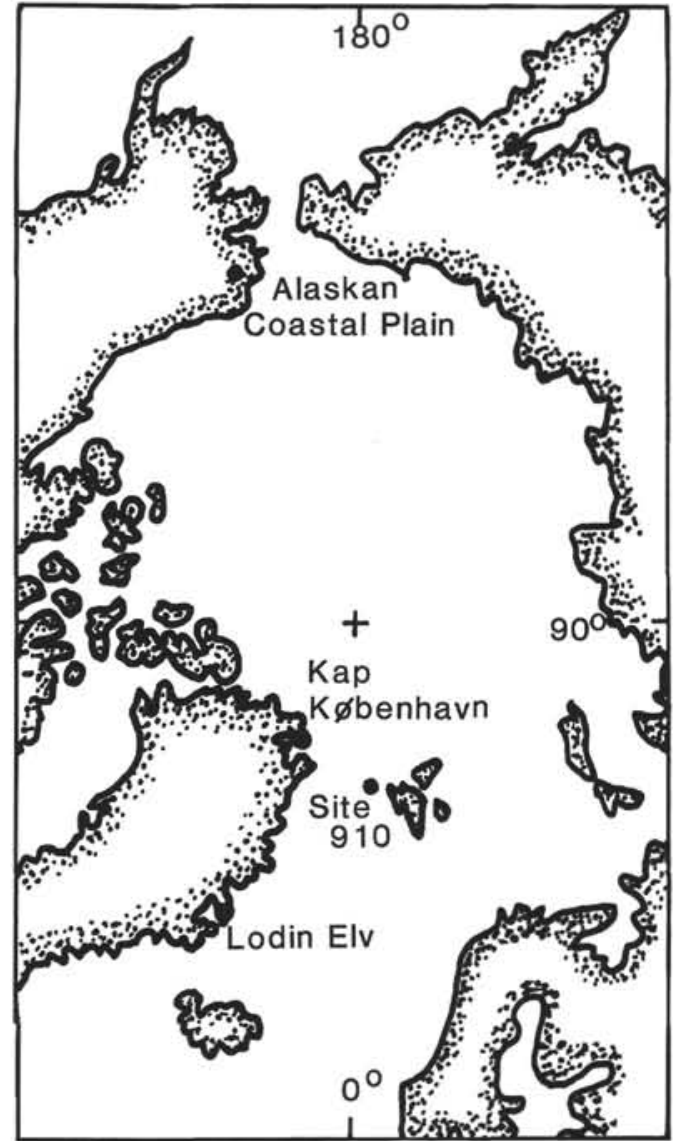

Figure 1. Location of Site 910 in comparison to other Pliocene sections, Kap København, Lodin Elv, and the Alaskan Coastal Plain.

not analyzed. Shipboard core-catcher samples processed on board the JOIDES Resolution were measured volumetrically and subjected to Calgon solution as well as sonic vibration (Shipboard Scientific Party, 1995).

\section{AGE CONTROL}

The upper $100 \mathrm{~m}$ of Hole $910 \mathrm{C}$ is identified as Quaternary, but is plagued with poor recovery and the presence of one or more intervals of overconsolidated sediment (see Rack et al., this volume, chapter 21 ; Flower, this volume). The uppermost overconsolidated zone occurs at $19 \mathrm{mbsf}$ in Hole $910 \mathrm{~A}$, and can be assumed to be close to that depth in Hole 910C. The Quaternary/Pliocene boundary is poorly constrained within the interval of no recovery from Sample 151910C-8R-CC (73.8 mbsf) to Sample 151-910C-11R-CC (102.8 mbsf; Fig. 2). Calcareous nannofossils, as well as benthic and planktonic foraminifers all suggest an age near the Quaternary/Pliocene boundary (1.6 Ma) for Sample 151-910C-11R-CC (102.8 mbsf; Shipboard Scientific Party, 1995). New nannofossil data place the boundary at 67 mbsf, slightly above Sample 910C-8R-CC (73.8 mbsf; Hull et al., this volume; Sato and Kameo, this volume).

All microfossil groups indicate that the interval from Sample 151910C-12R-CC (112.4 mbsf) to the base of the hole (504.7 mbsf) is clearly of Late Pliocene age (NN15-18). Cronin (this volume) reports the presence of the ostracode Pterygocythereis vannieuwenhuisei in Samples 151-910C-45R-CC (429.3 mbsf) to 151-910C-43R-CC (410.78 mbsf). This indicates an age of $\geq 2.5 \mathrm{Ma}$ for these samples. Assuming a uniform sedimentation rate (between 102.8 and 429.3 mbsf), an age of $2.7 \mathrm{Ma}$ is extrapolated for the base (507.4 mbsf). This age is in agreement with the recognition of Pacific benthic foraminifers, including Paracassidulina neocarinata, Globocassidulina grooviapeture, and Paracassidulina sagamenensis in Sample 151910C-53R-CC (507.4 mbsf), indicating that it must have been deposited after the opening of the Bering Straits at approximately $3.0 \mathrm{Ma}$ (Shipboard Scientific Party, 1995).

The magnetic record shows normally magnetized sediments throughout Hole 910A (24.71 mbsf). Poor recovery and strong concentrations of iron sulfides limited the magnetic stratigraphy in Hole 910C (Shipboard Scientific Party, 1995; Cande and Kent, 1992).

\section{RESULTS}

The benthic foraminifers of Hole $910 \mathrm{C}$ can be divided into four assemblage zones (Fig. 2). The upper two (the Elphidium excavatum f. clavata and Elphidium albiumbilicatum) zones indicate glacial conditions, while the lower two (the Elphidium spp. and Cassidulina spp.) zones show evidence of a more ameliorated pre-glacial environment.

The uppermost zone occurs from Sample 151-910C-1R-1, $1 \mathrm{~cm}$ (0.01 mbsf) to Sample 151-910C-8R-CC (73.8 mbsf) and contains foraminifers indicating both glacial and interglacial climatic conditions, including the highest percentages of $E$. excavatum $\mathrm{f}$. clavata. Elphidium excavatum f. clavata is common in Pleistocene glacialmarine sediments in the Arctic (Osterman, 1984; Osterman et al., 1985). Samples indicative of glacial stages contain lower diversities (number of species, $S,=5-9$ ). Samples indicative of interglacial stages contain higher diversities $(\mathrm{S}=13-19)$.

The $E$. excavatum $\mathrm{f}$. clavata zone includes the overconsolidated interval at 19 mbsf that was identified by physical properties (Shipboard Scientific Party, 1995). The cause of the overconsolidated interval was reported to be overcompacted due to excessive glacial dropstones or the grounding of glacial ice on the Yermak Plateau (Shipboard Scientific Party, 1995; Rack et al., this volume). Whatever the cause of the overconsolidated layer it certainly represents a major climatic event on the Yermak Plateau, and, as might be expected, the foraminifers differ somewhat above and below the uppermost overconsolidated layer, mainly in overall foraminiferal abundances. Sediments above the uppermost overconsolidated interval are believed to be younger than Oxygen Isotope Stage 15 (Flower, this volume). Modern oceanographic conditions are represented by the uppermost Samples 151-910C-1R,1 cm (0.01 mbsf) and 151-910C-1R, 3-7 cm (0.03 mbsf), which contains a benthic foraminifer assemblage dominated by branching and tubular agglutinated foraminifers including Bathysiphon major, Bathysiphon rufus, Rhabdamina abyssorum, Astrorhiza limnicola, Saccorhiza ramosa, and Reophax scorpiurus; rare calcareous species include Cassidulina teretis, Cassidulina reniforme, Cibicides lobatulus, and Nonion barleeanum. Beneath this uppermost agglutinated-foraminifer-rich sediment the remaining glacial-marine sediments of this upper interval from Sample $151-910 \mathrm{C} 1 \mathrm{R}-1,83-87 \mathrm{~cm}(0.83 \mathrm{mbsf})$ to the overconsolidated interval at $19 \mathrm{mbsf}$ contains a fairly consistent assemblage of predominately calcareous benthic foraminifers including additional calcareous species Epistominella vitrea, Stainforthia concava, and Stainforthia feylingi.

Beneath the overconsolidated interval, from 19 to $102.8 \mathrm{mbsf}$ (including Samples 151-910C-4R-3, 104-109 cm to 8R-CC), the lower part of the E. excavatum f. clavata zone occurs. Owing to both the overcompacted nature of the sediment and the abundance of dropstones, recovery was poor in the interval from 19 to $73.8 \mathrm{mbsf}$. Most of the samples below 19 mbsf contain only rare foraminifers with a few exceptions seen in Table 1. Samples 151-910C-4R-3, 104-109 $\mathrm{cm}$ (30.44 mbsf), 151-910C-5R-1, 103-108 cm (36.9 mbsf), and $151-910 \mathrm{C}-8 \mathrm{R}-2,20-23 \mathrm{~cm}$ ( $65.9 \mathrm{mbsf})$ contain higher diversity for- 


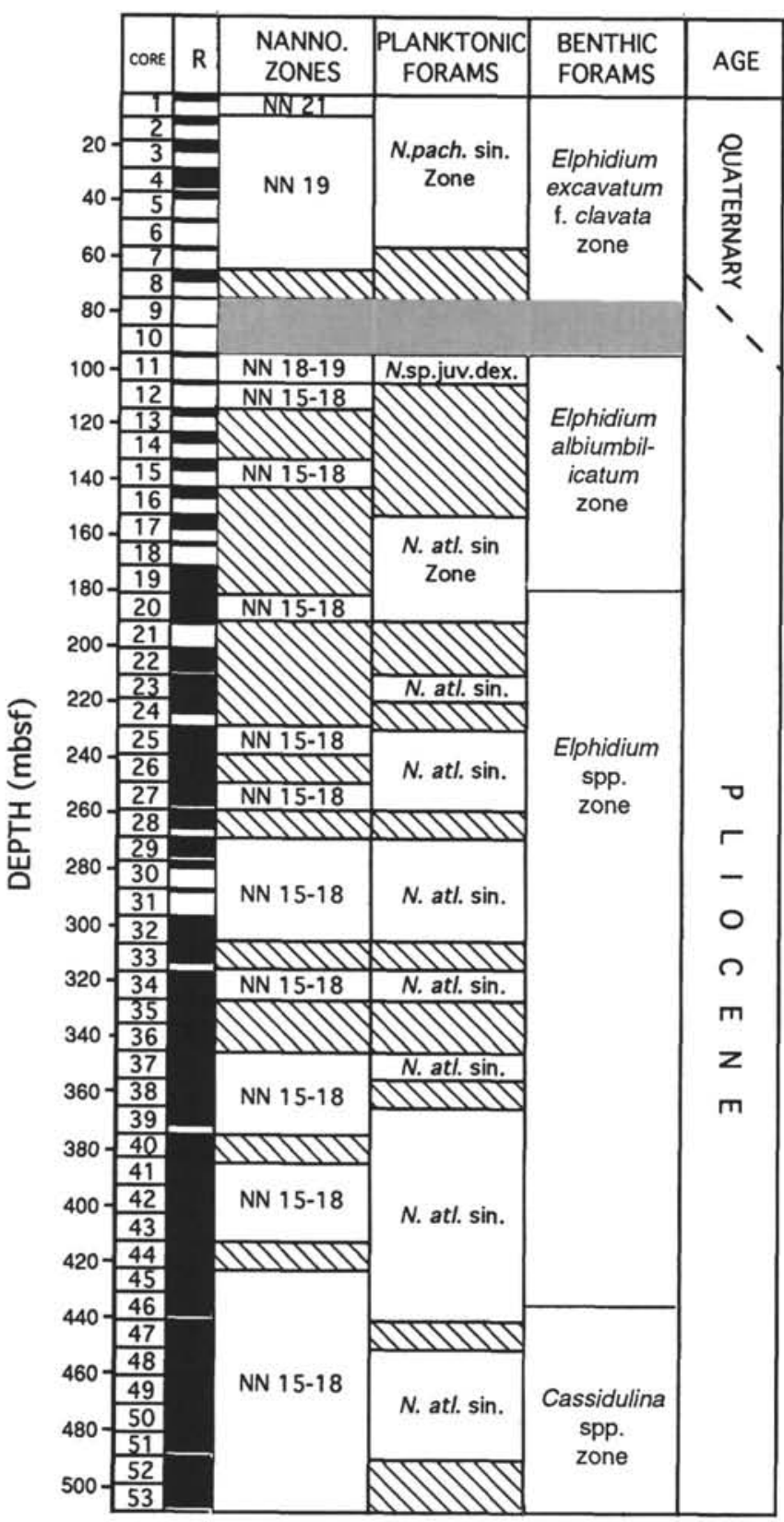

Figure 2. Biostratigraphic summary of Hole $910 \mathrm{C}$ including from left to right: depth (mbsf), core numbers, recovery, nannofossil zones, planktonic foraminiferal zones, benthic foraminiferal zones discussed in this paper, and age. Quaterary/Pliocene boundary now placed at $67 \mathrm{mbsf}$.

aminiferal assemblages indicating Pleistocene interglacial conditions. In addition, there was good recovery of Cores 151-910C-4R, $5 R$, and $8 R$, when compared to the other cores between 19 and 102.8 mbsf. This suggests that there might have been several episodes of severe glaciation, evidenced by poor recovery, as well as climatic amelioration, evidenced by good recovery, on the Yermak Shelf during the Quaternary ice ages.

The Quaternary E. excavatum f. clavata zone also includes increased numbers of reworked benthic foraminiferal specimens. In Quaternary sediments on Arctic continental shelves reworked specimens represent a problem. Often the reworked specimens can be identified by a worn or abraded texture or by a different color or broken test, in which case they are counted as reworked and not included in the foraminiferal percentages of Table 1. However, not all reworked specimens can be easily identified by their appearance; some are identified as reworked by ecological or temporal displacement. Species of Elphidium are usually restricted to shallow water and are common in proximal glacial-marine environments (Osterman, 1984), so it is possible that a majority of the Elphidium specimens in this uppermost zone of Hole $910 \mathrm{C}$ are ice-rafted into this water depth. The nature of other specimens is not so clear. In the Arctic, Cibicides grossa has been traditionally used to identify Pliocene deposits (King, 1983; McNeil, 1989; Knudsen and Asbjørnsdöttir, 1991). Therefore, the presence of Cibicides grossa in the Quaternary sediments of Hole $910 \mathrm{C}$ is assumed to have been due to reworking and ice rafting. However, the well-preserved nature of $C$. grossa in the Quaternary sediments suggests caution in the use of this species as a Pliocene marker at this latitude.

The second benthic foraminifer zone, the Elphidium albiumbilicatum zone, occurs from Sample 151-910C-11R-CC (102.8 mbsf) to 151-910C-20R-3, 133-136 cm (184.13 mbsf) and has been determined to be of latest Pliocene based on calcareous nannofossils and planktonic foraminifers (Shipboard Scientific Party, 1995). This zone is characterized by the presence of E. albiumbilicatum in most samples. Also characteristic of this zone is high percentages of Cassidulina reniforme and lower percentages of $C$. teretis. Cibicides grossa is also found in this zone. The number of species in this zone ranges from 2 to 23 (avg. $\mathrm{S}=10$ ) and the number of foraminifers per $\mathrm{cm}^{3}$ ranges from 2 to $68\left(\mathrm{avg} .=21\right.$ per $\left.\mathrm{cm}^{3}\right)$.

Elphidium albiumbilicatum is an Atlantic Ocean boreal water indicator, first recorded in the Sangamon deposits of Long Island, NY (Weiss, 1954). On the other hand, Cassidulina reniforme is a polar species and indicative of proximal glacial-marine environments (Sejrup and Guilbault, 1980; Osterman, 1984; Elverhoi et al., 1980). Therefore, the benthic foraminifers of this zone indicate both arctic and boreal conditions (i.e., glacial intervals, with episodes of warmer interglacials). This is also consistent with the interpretation of both pollen (Willard, 1995, this volume), ostracodes (Cronin, 1995, this volume), and sediments (Shipboard Scientific Party, 1995) over the same interval. This foraminifer zone occurs below the interval of poor recovery and slightly above the first dropstone occurrence at 208.7 mbsf. It appears as though the environmental change in the benthic foraminiferal assemblages occurred somewhat later than the sedimentological indicators for increased glaciation. This suggests that there is a lag between the time of ice build up, reflected by the dropstones, and the time of oceanic cooling, reflected by the foraminiferal change.

Reworking of the foraminiferal fauna appears to be less common in the E. albiumbilicatum zone than in the uppermost zone, but icerafting of benthic foraminifers, as well as other fossil groups, certainly occurred. Evidence is seen in the interval from Sample 151-910C17R-CC (161.15 mbsf) to Sample 151-910C-20R-CC (187.84 mbsf) which contains reworked Miocene diatoms and radiolarians (Shipboard Scientific Party, 1995).

The third benthic foraminiferal zone occurs from Sample 151910C-21R-1, 27-30 cm (189.67 mbsf) to $151-910 C-43 R-6,80-83$ $\mathrm{cm}$ (409.5 mbsf). The benthic foraminifer assemblage is characterized by the occurrence of large-sized elphidium including Elphidium excavatum, Elphidium groenlandicus, Elphidiella hanni, and Elphidiella hughesi. Elphidiella hughesi and $E$. hanni were originally described from the Pliocene of California (Cushman and Grant, 1927). Nonion matchigaricus, originally described from the Miocene deposits of Sakhalin, Russia in the North Pacific (Volshinova, 1952) was also observed in this zone. Epistominella vitrea is also common in this zone. There is a wide range of diversity and abundance values in this zone which includes a benthic foraminiferal low-diversity zone, recognized by the Shipboard Scientific Party (1995), from Samples 151-910C-33R-CC to $38 \mathrm{R}-\mathrm{CC}$ (314.8 to $362.9 \mathrm{mbsf}$ ). The number of species ranges from 2 to 18 (avg. $\mathrm{S}=8$ ) and the number of foramin- 
Table 1. Most abundant species percentages, Hole 910C.

\begin{tabular}{|c|c|c|c|c|c|c|c|c|c|c|c|c|c|c|c|c|c|c|c|c|}
\hline $\begin{array}{l}\text { Core, section, } \\
\text { interval }(\mathrm{cm})\end{array}$ & $\begin{array}{l}\text { Depth } \\
\text { (mbsf) }\end{array}$ & 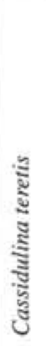 & 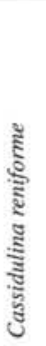 & 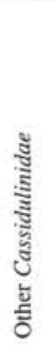 & 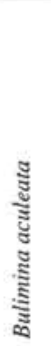 & 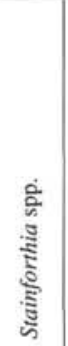 & 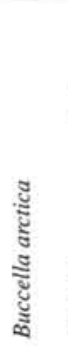 & 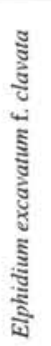 & 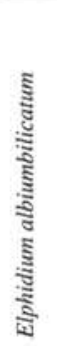 & 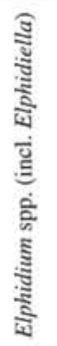 & 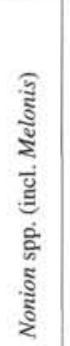 & 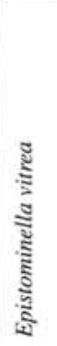 & 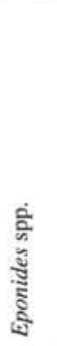 & 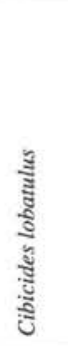 & 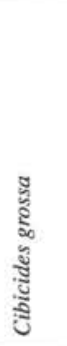 & 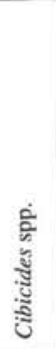 & 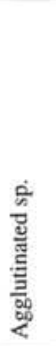 & 总 & 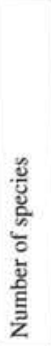 & 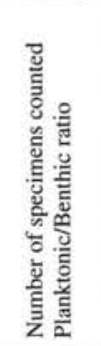 \\
\hline $151-910 \mathrm{C}-$ & & & & & & & & & & & & & & & & & & & & \\
\hline $\begin{array}{l}\text { IR-1, 1 } \\
\text { IR-1,3-9 }\end{array}$ & $\begin{array}{l}.01 \\
.03\end{array}$ & $\begin{array}{r}19 \\
6\end{array}$ & $\begin{array}{r}22 \\
2\end{array}$ & 4 & & $\begin{array}{l}2 \\
4\end{array}$ & 2 & 5 & 1 & & $\begin{array}{l}6 \\
8\end{array}$ & 3 & $\begin{array}{l}2 \\
6\end{array}$ & $\frac{1}{2}$ & & & $\begin{array}{l}36 \\
58\end{array}$ & $\begin{array}{r}3 \\
10\end{array}$ & $\begin{array}{l}18 \\
17\end{array}$ & $\begin{array}{c}43 / 132 \\
4 / 63\end{array}$ \\
\hline IR-1, 83-87 & .83 & 27 & 36 & & & 11.0 & 1 & 6 & & & $\begin{array}{l}\circ \\
3\end{array}$ & 3 & 7 & 4 & & & 1 & 1 & 16 & $2 / 80$ \\
\hline IR-CC, 7-11 & 1.57 & 12 & 34 & & 3 & 15 & 1 & 11 & 1 & & 5 & 10 & 7 & & & & & 1 & 13 & $0 / 145$ \\
\hline $2 \mathrm{R}-1,76-80$ & 9.26 & 12 & 18 & & 2 & 9 & & 10 & 1 & 1 & 8 & 33 & 1 & & & & & 6 & 19 & $153 / 230$ \\
\hline $2 \mathrm{R}-\mathrm{CC}$ & 17.4 & 22 & 12 & & & 1 & & 22 & 1 & & 10 & 17 & 7 & 2 & & & & 6 & 14 & $51 / 147$ \\
\hline $3 R-1,40-44$ & 17.8 & 14 & 17 & 1 & 1 & 4 & 1 & 10 & i & & 4 & 42 & 2 & 4 & & & & 1 & 14 & $41 / 157$ \\
\hline $4 \mathrm{R}-3,104-109$ & 30.44 & 10 & 11 & & & & 2 & 11 & 2 & & & 51 & 1 & 4 & & & & 7 & 15 & $30 / 203$ \\
\hline $5 \mathrm{R}-1,103-108$ & 36.33 & 19 & 9 & & & 2 & & 9 & & 1 & 4 & 44 & & & 4 & & & 7 & 16 & $55 / 211$ \\
\hline $6 \mathrm{R}-1,20-23$ & 45.10 & $*$ & $*$ & & & & * & $*$ & & & * & $*$ & & & * & & & & 7 & $2 / 38$ \\
\hline $8 \mathrm{R}-1,18-22$ & 65.38 & 17 & 21 & & & 5 & 2 & 11 & 5 & & 5 & 26 & & 7 & & & & 1 & 9 & $2 / 42$ \\
\hline $8 \mathrm{R}-2,20-23$ & 65.9 & 27 & 21 & 2 & & 10 & 8 & 13 & 1 & & 4 & 10 & & & & & & 4 & 14 & $5 / 155$ \\
\hline $8 \mathrm{R}-\mathrm{CC}$ & 73.8 & $*$ & $\because$ & & & & & & & & * & & & * & & & & * & 5 & $0 / 11$ \\
\hline $11 \mathrm{R}-\mathrm{CC}$ & 93.29 & 9 & 11 & .4 & & 1 & 5 & 7 & 2 & & 4 & 52 & & .4 & 2 & & & 6 & 23 & $3 / 257$ \\
\hline $13 R-1,85-88$ & $\begin{array}{r}70.29 \\
113.25\end{array}$ & * & $*$ & .4 & & 1 & * & 1 & ${ }^{2}$ & * & $*$ & 52 & & 14 & 2 & & & & 6 & $0 / 6$ \\
\hline $13 \mathrm{R}-2,45-48$ & 114.35 & $*$ & & & & & * & & * & * & * & & & & & * & & & 6 & $0 / 8$ \\
\hline $14 \mathrm{R}-1,130-134$ & 123.3 & 17 & 15 & & & & & & 29 & 14 & & 7 & & & 14 & & & 4 & 8 & $0 / 52$ \\
\hline $15 \mathrm{R}-1,68-72$ & 132.28 & $*$ & & & & & & & & & & & & & & * & & & 2 & $0 / 7$ \\
\hline $17 \mathrm{R}-1,37-41$ & 151.27 & * & $*$ & & & & * & * & * & & * & * & & * & * & & & * & 11 & $3 / 37$ \\
\hline $17 \mathrm{R}-2,37-41$ & 152.77 & * & * & & & & * & * & * & & * & & & & * & & & * & 10 & $0 / 41$ \\
\hline $17 R-3,37-41$ & 154.27 & & & & & & & & & & & & & & & & & & 0 & 0 \\
\hline $19 \mathrm{R}-1,3$ & 170.54 & 8 & 65 & & & & & 2 & 4 & & 2 & 8 & 6 & 1 & & 2 & & 2 & 11 & $0 / 171$ \\
\hline $19 \mathrm{R}-2,34-38$ & 172.04 & 2 & 66 & & & & & 11 & & & 6 & & 1 & & 2 & & 7 & 5 & 8 & $2 / 96$ \\
\hline $20 \mathrm{R}-2,46-49$ & 181.76 & 4 & 25 & & & & 8 & 8 & 18 & & 23 & 1 & 4 & 6 & 1 & & & 2 & 16 & $0 / 83$ \\
\hline 20R-3, 133-136 & 184.13 & 3 & 44 & & & & & & $\begin{array}{l}18 \\
18\end{array}$ & & 3 & 1 & 13 & & 11 & & 4 & 3 & 10 & $5 / 195$ \\
\hline $21 \mathrm{R}-1,27-30$ & 189.67 & & & & & & & & & & & & & & & & & & 0 & 0 \\
\hline $22 \mathrm{R}-1,27-30$ & 199.27 & & & & & & & & & & & & & & & & & & 0 & 0 \\
\hline $22 \mathrm{R}-1,136-138$ & 200.36 & & & & & & & & & & & & & & & & & & 0 & \\
\hline $22 R-4,28-31$ & 203.78 & 32 & 18 & 3 & & & & 2 & & 37 & 6 & & & & & & & 2 & 8 & $4 / 110$ \\
\hline $22 \mathrm{R}-5,35-38$ & 205.35 & $*$ & $*$ & & & & & & & & * & & & & & & & $=$ & 6 & $0 / 17$ \\
\hline $23 \mathrm{R}-3,34-36$ & 212.04 & 55 & 9 & & & 2 & & 2 & 5 & 20 & 6 & & & & & & & 1 & 8 & $0 / 65$ \\
\hline $23 \mathrm{R}-5,34-36$ & 215.04 & $*$ & $*$ & & & & & & * & $\approx$ & * & * & $*$ & & & & & * & 9 & $2 / 47$ \\
\hline $24 \mathrm{R}-1,129-132$ & 219.59 & 14 & 2 & & & 10 & & 3 & 3 & 46 & 8 & & 1 & 1 & 4 & & & 8 & 14 & $1 / 116$ \\
\hline $25 \mathrm{R}-2,61-67$ & 230.11 & 10 & 70 & 3 & & & & 7 & & 3 & 4 & & 3 & & & & & & 8 & $0 / 72$ \\
\hline $25 \mathrm{R}-\mathrm{CC}$ & 236.54 & 15 & 53 & 1 & & & & 1 & & 15 & 4 & 4 & & 15 & & 1 & 1 & 6 & 13 & $1 / 140$ \\
\hline $26 \mathrm{R}-2,80-83$ & 239.9 & 18 & 52 & & & & 9 & 1 & 1 & 13 & 3 & 4 & & 10 & & . & 2 & 3 & 9 & $0 / 111$ \\
\hline $27 \mathrm{R}-4,79-85$ & 252.49 & 23 & 15 & & & & & & & & 6 & 47 & & & & & & 8 & 9 & $2 / 66$ \\
\hline $28 \mathrm{R}-2,78-82$ & 259.18 & $*$ & & & & & & & & & 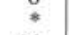 & & & & & & & & 2 & $0 / 3$ \\
\hline $29 \mathrm{R}-2,77-82$ & 267.79 & 3 & 35 & & & 3 & 5 & & 1 & 1 & 46 & 1 & & & & & & 3 & 3 & $1 / 105$ \\
\hline $29 \mathrm{R}-4,77-82$ & 270.79 & 18 & 30 & & & 1 & 4 & 4 & i & 29 & & 7 & & .4 & & & 5 & 1 & 18 & $6 / 229$ \\
\hline $32 \mathrm{R}-2$ & 296.80 & $*$ & $*$ & & & & & * & & & & & & & & & & $*$ & 4 & $0 / 16$ \\
\hline $32 \mathrm{R}-4,80-83$ & 299.8 & $*$ & $*$ & & & & * & & & & & & & & & & & & 3 & $0 / 14$ \\
\hline & 301.3 & 15 & 57 & 1 & & & 3 & 2 & 5 & & & 1 & 16 & 3 & & & & & 9 & $2 / 106$ \\
\hline $32 \mathrm{R}-6,80-83$ & 302.76 & 41 & 46 & & & 1 & 1 & 3 & & 3 & & & 4 & & & & & 2 & 9 & $5 / 121$ \\
\hline $33 \mathrm{R}-2,76-80$ & 307.36 & & & & & & & & & & & & & & & & & & 0 & $=0$ \\
\hline $34 \mathrm{R}-2,83-87$ & 317.13 & & & & & & & & & & & & & & & & & & 0 & 0 \\
\hline $35 R-4,82-86$ & 329. & $*$ & $*$ & & & & & & & * & * & & & & * & & & & 5 & $3 / 43$ \\
\hline $36 \mathrm{R}-5,78-82$ & 340.88 & 14 & 17 & 4 & & & 1 & 2 & 1 & 1 & 1 & 44 & 12 & & & & 1 & 1 & 16 & $10 / 270$ \\
\hline $37 \mathrm{R}-3,96-100$ & 347.76 & 5 & 41 & .3 & & & .6 & & & 1 & .6 & 40 & 7 & & & & 2 & 2 & 14 & $2 / 354$ \\
\hline $37 \mathrm{R}-5,96-100$ & 350.76 & 22 & 10 & & & & & & & & 18 & 15 & 12 & & & & & 23 & 8 & $5 / 69$ \\
\hline $39 \mathrm{R}-2,79-83$ & 365.18 & 35 & 18 & & & 1 & 1 & & & & 29 & 14 & & & & & & 3 & 8 & $5 / 108$ \\
\hline $40 R-2,77-83$ & 374.67 & & 10 & & & & & & & & & & & & & & & & 0 & 0 \\
\hline $40 R-5,77-83$ & 379.17 & * & $*$ & & & & & & & & * & * & & & & & & * & 5 & $0 / 35$ \\
\hline$-6,77-83$ & 0.67 & 32 & 31 & & & .5 & & & & 1 & 2 & 30 & & & & & 1 & 1.5 & 9 & $3 / 207$ \\
\hline 4IR-2, 74-77 & 384.1 & $*$ & $*$ & & & & & * & & & * & $*$ & & & & & * & $*$ & 7 & $1 / 48$ \\
\hline 6 & 3 & 22 & 13 & & & 2 & 2 & 2 & & & 22 & 9 & & & & 2 & & 26 & 10 & $2 / 54$ \\
\hline 73- & 390.1 ? & 38 & 14 & 3 & & & & 1 & 1 & & 29 & 4 & & & & 3 & & 7 & 12 & $1 / 77$ \\
\hline $42 \mathrm{R}-2,80-83$ & 393.8 & $*$ & $*$ & & & & & $*$ & & & $*$ & & & & & & & * & 5 & $0 / 22$ \\
\hline $42 R-4,80-83$ & 396.8 & * & $*$ & & & & & & & & * & & & & & & & * & 4 & $0 / 12$ \\
\hline $42 \mathrm{R}-6,80-83$ & 399.8 & * & $*$ & & & & & & & & & & & & & & & & 2 & $0 / 2$ \\
\hline 43 & & 14 & 10 & & & & & & & & 59 & 14 & & & & & 3 & & 5 & $6 / 59$ \\
\hline 43 & & $*$ & & & & & & & & & & & & & & & & & 2 & $0 / 2$ \\
\hline $43 \mathrm{R}-6,8 \mathrm{C}$ & .5 & $*$ & $*$ & & & & & & & & * & $*$ & & & & & * & * & 7 & $1 / 37$ \\
\hline $46 \mathrm{R}-4,1$ & .7 & 39 & 21 & & & & & 3 & & 1 & 9 & 18 & & & & & 4 & 5 & 14 & $21 / 358$ \\
\hline 47 & & 15 & 5 & & & & 19 & & 7 & & 32 & & & & 2.5 & & & 15 & 12 & $0 / 81$ \\
\hline 48 & & 19 & 8 & & & & & & 1 & & 21 & 41 & & & 2 & & & 8 & 9 & $0 / 103$ \\
\hline $49 \mathrm{R}-1,74-78$ & 459.74 & 27 & 5 & 2 & & & & & i & & 15 & 24 & & & 3 & & & 19 & 16 & $11 / 86$ \\
\hline $49 \mathrm{R}-2,74-78$ & 461.26 & 22 & 17 & 4 & & & & & & & 6 & 45 & & & & & 4 & 4 & 7 & $3 / 139$ \\
\hline $50 \mathrm{R}-4,80-83$ & 474. & & & & & & & & & & & & & & & & & & 0 & 0 \\
\hline $50 \mathrm{R}-6,80-83$ & 477. & * & & & & & & & & * & * & & & & * & & & & 4 & $0 / 4$ \\
\hline 2,7 & 480.69 & & & & & & & & & & & & & & & & & & 0 & 0 \\
\hline$-4,79-85$ & 483.69 & 25 & 43 & & & & .4 & 2 & & 1 & 5 & 7 & 6 & & & & & 11 & 14 & $35 / 272$ \\
\hline $52 \mathrm{R}-2,80-83$ & 490.3 & & & & & & & & & & & & & & & & & & 0 & \\
\hline $52 \mathrm{R}-4,80-83$ & 493.3 & 8 & 34 & & & & & & & & 13 & 25 & 14 & & & & & 6 & 9 & $3 / 88$ \\
\hline $52 \mathrm{R}-6$ & 496 & 10 & 5 & & & & & & & 1 & 12 & 64 & 6 & & & & & 2 & 8 & $3 / 86$ \\
\hline $53 \mathrm{R}-2,7$ & 499 & $*$ & & & & & & * & & * & $*$ & & & & * & * & & * & 11 & $1 / 28$ \\
\hline $53 R-4,77-81$ & 502.97 & 10 & 23 & 2 & & 3 & 3 & & & & 5 & 51 & & & 1 & & & 1 & 10 & $3 / 92$ \\
\hline
\end{tabular}

Note: Others $=$ all other species occurring in sample; ${ }^{*}=$ species present but percentage not calculated if total $\mathrm{B}<40$. 
ifers per $\mathrm{cm}^{3}$ ranges from $2-108\left(\mathrm{avg} .=26\right.$ per $\left.\mathrm{cm}^{3}\right)$. Wood and plant fragments are found in the interval from Samples 151-910C-25R-CC (236.54 mbsf) to 151-910C-39R-CC (386.9 mbsf) (Shipboard Scientific Party, 1995) suggesting warm forested conditions within the Arctic. There does not appear to be any strong glacial influence in this assemblage, and no dropstones were recognized (Shipboard Scientific Party, 1995).

The lowest zone is designated the Cassidulina spp. zone and occurs from Sample 151-910C-46R-4, 110-114 (435.5 mbsf) to the base of the hole at $504.7 \mathrm{mbsf}$. The foraminiferal diversity and abundance of this zone is the highest in the Pliocene. The number of species ranges from 4 to 16 (avg. $\mathrm{S}=10$ ) and the number of foraminifers per $\mathrm{cm}^{3}$ ranges from 2-143 (avg. $=56$ per $\mathrm{cm}^{3}$ ). The oldest sediments in Hole $910 \mathrm{C}$ show increased benthic foraminiferal diversity of the Cassidulinid species, in particular the carinate forms including Cassidulina pliocarinata and Paracassidulina neocarinata. Several species show Pacific affinities including Globocassidulina grooviapeture, Paracassidulina neocarinata, and Paracassidulina sagamenensis (Nomura, 1983a, 1983b; Matoba et al., 1990). Nonion erucopsis, originally described from Carter Creek, Alaska (Todd, 1957), is also found in this zone. It is most important to recognize that this assemblage zone has an increase in the number and diversity of planktonic foraminifers. Sample 151-910C-51R-4, 79-85 cm (483.69 mbsf) contains the largest number of planktonic foraminifers in all Pliocene samples, which indicates the warmest water during the deposition of these sediments. Planktonic species Neogloboquadrina atlantica both dextral and sinistral are found throughout this interval, as well as sporadically in the other zones. Other planktonic species, including Globigerina quinqueloba (Sample 151-910C-49R-1, 74-78 cm [459.74 mbsf]), and Globigerina bulloides (Sample 151-910C-51R$4,79-85 \mathrm{~cm}$ [483.69 mbsf]), are found only in this lowermost zone.

\section{DISCUSSION}

The purpose of this paper is to provide a benthic foraminiferal zonation that will allow comparison to other Pliocene marine sediments of the Arctic. Preliminary analysis suggests that there are several similarities between the Pliocene section of Hole 910C and other Pliocene-aged sediments in the Arctic, in particular the Lodin Elv and Kap København Formations of Greenland and the Pliocene marine transgressions of the Alaskan Arctic Coastal Plain (Feyling-Hanssen et al., 1982; Feyling-Hanssen, 1990; Brigham-Grette and Carter, 1992). All of these sites contain evidence for several Pliocene events which I believe can be correlated based on the benthic foraminifers.

Three warm Pliocene marine transgressions have been reported from the Alaskan Coastal Plain (Brigham-Grette and Carter, 1992). These are tentatively dated as the Covillian Transgression ( 2.7 to 2.48 $\mathrm{Ma}$ ), the Bigbendian Transgression (around $2.48 \mathrm{Ma}$ ), and the Fishcreekian Transgression (2.48 to $2.14 \mathrm{Ma}$ ) (Brigham-Grette and Carter, 1992). Macrofaunal evidence suggests that these were warm water transgressions that became progressively cooler from oldest to youngest. The timing of these transgressions is important to Arctic stratigraphy. Unfortunately, most Alaskan samples contain very few benthic foraminifers; however, samples of the youngest Pliocene unit, the Fishcreekian Transgression, do contain large Elphidium including E. hughesi (Osterman, unpubl. data). This correlates strongly with the Elphidium spp. zone of Site 910.

In eastern Greenland, Pliocene benthic foraminifers from the Lodin Elv Formation $\left(71^{\circ} 10^{\prime} \mathrm{N}, 24^{\circ} 24^{\prime} \mathrm{W}\right)$ have been reported by Feyling-Hanssen et al., (1982). The Lodin Elv Formation represents an inner shelf environment and is believed to straddle the Pliocene/Quaternary boundary (Feyling-Hanssen, 1985, 1990; Feyling-Hanssen et al., 1982). The benthic foraminiferal assemblages are divided into a lower Zone I with C. grossa, C. reniforme, and E. vitrea, and the upper Zone II without $C$. grossa. Placing the Pliocene/Quaternary boundary between Zones I and II is based on the presence/absence of
C. grossa at Lodin Elv. The study of Site 910 has shown that the stratigraphic use of $C$. grossa alone may be suspect. I would propose that the entire Lodin Elv formation appears to correlate to the uppermost Pliocene deposits of Site $910 \mathrm{C}$ with increased percentages of $C$. reniforme and $E$. vitrea.

The Kap København Formation $\left(82^{\circ} 30^{\prime} \mathrm{N}, 21^{\circ} \mathrm{W}\right)$ is also believed to have been deposited in an inner shelf environment during the late Pliocene to early Quaternary. Both ostracodes (Brouwers et al., 1991) and benthic foraminifers (Feyling-Hanssen, 1990) have been studied. The Kap København Formation is subdivided into four members, from bottom to top, A, B1, B2, and B3 (Funder et al., 1985). Members B2 and B3 contain glacial dropstones along with abundant wood fragments, which suggests a warm, forested Arctic with nearby mountain glaciers. Funder et al., (1985) believe that the climate of Northern Greenland during the deposition of the Kap København formation was similar to present-day Labrador.

Benthic foraminifers are found in Kap København members A and B2. Member A contains $N$. erucopsis, C. reniforme, C. teretis, and C. laevigata (which Feyling-Hanssen [1990] reports as being very close to $C$. pliocarinata). Feyling-Hanssen (1990) also reports that Kap København has numerous similarities to Japanese faunas, including P. sagminensis (Asano and Nakamura, 1937) found in member A. The foraminiferal assemblage of Member A is very similar to the Cassidulina spp. zone of Site 910C, which also includes $N$. erucopsis, C. pliocarinata, and P. sagmenensis.

The lower part of Kap København member B2 contains various large elphidium including Elphidium rolfi, E. hanni, and E. hughesi, as well as Nonion niveum $(=N$. tallahattensis of Feyling-Hanssen [1976] and reported to be similar to Nonion akitaensis Asano, [1950]). The upper part of member B2 contains increased E. albiumbilaticum, $C$. reniforme, and $E$. vitrea. Member B has similarities to both the Elphidium spp. and E. albiumbilicatum zones of Site 910C.

The age and stratigraphy of the Kap København Formation is still disputed. Feyling-Hanssen (1990) reports that member B2 of the Kap København Formation straddles the Pliocene/Quaternary boundary $(\approx 2$ ? Ma) which agrees with Brigham-Grette and Carter's $(1992)$ correlation of Kap København member B to the Fishcreekian transgression of the Alaskan Coastal Plain (2.14 to 2.48 Ma). This correlation also agrees with the occurrence of the large Elphidium in deposits of the Fishcreekian transgression, in member B of Kap København and in the Elphidium spp. zone of Hole 910C. Brigham-Grette and Carter (1992) correlate Kap København member A to the either the Covillian Transgression ( 2.7 to $2.48 \mathrm{Ma}$ ) or the Bigbendian Transgression $(\sim 2.48 \mathrm{Ma})$.

On the other hand, the ostracode fauna (Brouwers et al., 1991) of member B2 contains $P$. vannieuwenhuisei, which corresponds to the older Covillian Transgression (2.48 and 2.7 Ma) on the North Slope of Alaska. Regardless of the age, ostracodes from the Kap København Formation suggest that winter temperatures were $1-2^{\circ} \mathrm{C}$ warmer and summer temperatures were $7^{\circ}$ to $8^{\circ} \mathrm{C}$ warmer than present during this interval (Brouwers et al., 1991).

\section{SUMMARY}

It appears to be possible to correlate $400 \mathrm{~m}$ of Pliocene-aged continental shelf sediment in Hole 910C with the isolated pockets of Arctic Pliocene sediment that have been previously described. Some strong similarities exist. Hole $910 \mathrm{C}$ contains three separate Pliocene benthic foraminiferal zones that appear to have been deposited between 2.7 to $1.6 \mathrm{Ma}$. This agrees with the time span discussed by most of the previous researchers (Feyling-Hanssen, 1985, 1990; Feyling-Hansen et al., 1982; Brigham-Grette and Carter, 1992; Brouwers et al., 1991).

The benthic foraminifers in the three Pliocene zones of Site 910C indicate increasingly cooler conditions from Pliocene to Quaternary. Based on the numbers of planktonic foraminifers and benthic fora- 
miniferal abundances, the lowermost Cassidulina spp. zone indicates the warmest water conditions within the Pliocene at this locality. The Cassidulina spp. zone also shows an increased number of species with Pacific affinities. These include $G$. grooviapeture, $P$. neocarina$t a$, and $P$. sagmenensis. These species do not occur at this location today. The Cassidulina spp. zone appears to correlate to Member A of Kap København and either the Covillian Transgression (2.7 to 2.48 Ma) or the Bigbendian Transgression of the Alaskan Coastal Plain. The occurrence of the ostracode Pterygocythereis vannieuwenhuisei in Samples 151-910C-45R-CC (429.3 mbsf) to 151-910C-43R-CC (410.78 mbsf) suggests a correlation to the Covillian Transgression.

The Elphidium spp. zone of Site 910C indicates warm, but cooling, conditions with decreasing foraminiferal diversities and abundances ending with the initiation of glacial dropstones at $208.7 \mathrm{mbsf}$. This zone can be correlated to the lower part of Kap København Member B and the Fishcreekian transgression based on the occurrence of large Elphidium including $E$. hughesi at all three localities. The presence of Pacific species E. hughesi, E. hanni, and N. matchigaricus indicate a continuing Pacific influence at this site.

Climatic conditions changed during the latest Pliocene when Atlantic species began to dominate the sediments. Glacial-marine conditions with warm episodes are indicated in the upper Pliocene E. albiumbilicatum zone. A similar foraminiferal assemblage with increased E. albiumbilaticum, C. reniforme, and E. vitrea is recognized in the upper part of Kap København Member B as well as Zones I and II of Lodin Elv.

The uppermost Quaternary E. excavatum f. clavata zone ( 0 to $102.8 \mathrm{mbsf}$ ) records glacial and interglacial climatic fluctuations including one or more episodes of grounded glacial ice (or severe episodes of ice-rafting) and ice-free interglacial deposits. Poor recovery of these youngest sediments in Hole $910 \mathrm{C}$ limit further interpretation.

\section{ACKNOWLEDGMENTS}

I would like to thank co-chief scientists Annik Myhre and Jörn Thiede and the fellow shipboard scientists of Leg 151. I wish to thank Tom Ribbens, the crew and staff of the JOIDES Resolution. The Smithsonian Institution and the United States Geological Survey (Reston) are thanked for providing space to complete this research. I thank Detmar Schnitker for reviewing this manuscript.

\section{FAUNAL REFERENCE LIST}

\author{
Astrononion gallowayi Loeblich and Tappan \\ Astrorhiza limnicola Sandahl \\ Bathysiphon major de Folin 1886 \\ Bathysiphon rufus de Folin 1886 \\ Buccella arctica (Volshinova 1960) \\ Buccella frigida (Cushman) \\ Bulimina aculeata (d'Orbigny) \\ Cassidulina reniforme Nørving \\ Cassidulina teretis Tappan \\ Cassidulina pliocarinata van Vorthuysen \\ Cibicides grossa (Dam and Walker) \\ Cibicides lobatulus (Walker and Jacob) \\ Elphidium albiumbilicatum (Weiss) \\ Elphidium excavatum (Terquem) forma clavata Cushman \\ Elphidium groenlandicum Cushman \\ Elphidiella hanni Cushman and Grant \\ Elphidiella hughesi Cushman and Grant \\ Epistominella vitrea Parker \\ Guttulina yamazaki Cushman and Ozawa \\ Glandulina laevigata d'Orbigny \\ Globocassidulina grooviapeture $($ Nomura $)=$ Cassidulina gemma \\ Islandiella algida $($ Cushman $)=$ Islandiella islandica \\ Islandiella helenae Feyling-Hanssen and Buzas \\ Islandiella norcrossi (Cushman) \\ Miliolinella subrotunda (Montagu) \\ Nonion barleeanum (Williamson)
}

Nonion labradoricum (Dawson)

Nonion erucopsis Todd

Nonion matchigaricus Volshinova

Paracassidulina neocarinata (Nomura)

Paracassidulina sagminensis (Asano and Nakamura)

Pullina bulloides (d'Orbigny)

Pyrgo williamsoni (Silvestri)

Quinquloculina arctica Cushman

Quinquloculina stalkeri Loeblich and Tappan

Reophax scorpiurus de Montfort

Rhabdammina abssorum M. Sars

Saccorhiza ramosa (Brady)

Scutularis tegminis Loeblich and Tappan

Stainforthia concava (Höglund)

Stainforthia feylingi (Knudsen and Seidenkrantz)

Triloculina trihedra Loeblich and Tappan

\section{TAXONOMIC NOTES}

\section{Cibicides grossa}

This research seems to show that there may be two forms of Cibicides grossa. The broadly rounded and coarsely perforate form is found in the upper two zones of Hole 910C. Another form with a convex umbilical side and a somewhat keeled periphery is found in older sediments. Both forms appear to be figured by Dam and Reinhold (1941). More work is needed to understand the relationship of these two forms. In addition, caution is urged in the use of this species as a Pliocene indicator. Very fresh looking specimens of $C$. grossa (up to $4 \%$ ) occur in clearly Quaternary sediments.

\section{Cassidulina teretis}

In this study it was often difficult to determine the identification of the cassidulinids. Most specimens had broken apertures, making positive identification impossible, and were sufficiently frosted to make the recognition of bosses impossible. In these counts Cassidulina teretis includes all forms which could not be positively identified as I. helenae and I. norcrossi.

\section{REFERENCES}

Aagaard, K., Swift, J.H., and Carmack, E.C., 1985. Thermohaline circulation in the Arctic Mediterranean seas. J. Geophys. Res., 90:4833-4846.

Asano, K., 1950. Part 1: Nonionidae. In Stach, L.W. (Ed.), Illustrated Catalogue of Japanese Tertiary Smaller Foraminifera: Tokyo (Hosokawa).

Asano, K., and Nakamura, M., 1937. On the Japanese species of Cassidulina. Jpn. J. Geol. Geogr. Trans. Abstr., 14:147.

Brigham-Grette, J., and Carter, L.D., 1992. Pliocene marine transgressions of northern Alaska: circumarctic correlations and paleoclimate interpretations. Arctic, 45:74-89.

Brouwers, E.M., Jørgensen, N.O., and Cronin, T.M., 1991. Climatic significance of the ostracode fauna from the Pliocene Kap København Formation, north Greenland.Micropaleontology, 37:245-267.

Cande, S.C., and Kent, D.V., 1992. A new geomagnetic polarity time scale for the Late Cretaceous and Cenozoic. J. Geophys. Res., 97:1391713951.

Cronin, T., 1995. Microfaunal evidence for late Pliocene warm oceanic Atlantic water on the Yermak Plateau, eastern Arctic Ocean, from ODP Leg 151, Site 910. AGU Abstr., S167.

Cushman, J.A., and Grant, U.S., IV, 1927. Late Tertiary and Quaternary Elphidiums of the West Coast of North America. Trans. San Diego Soc. Nat. Hist., 4:69-82.

Dam, A.T., and Reinhold, T., 1941. Die stratigraphische Gliederung des niederlandischen Plio-Pleistozans nach Foraminiferen. Meded. Geol. Sticht., Ser. C-V.

Elverhoi, A., Liestol, O., and Nagy, J., 1980. Glacial erosion, sedimentation, and microfauna in the inner part of the Kongfjorden, Spitsbergen. Saertr. Norsk Polarinst.

Feyling-Hanssen, R.W., 1976. The Clyde Foreland formation: a micropaleontological study of Quaternary stratigraphy. 1st. Int. Symp. on Benthonic Foraminifera of Continental Margins (Pt. B): Paleoecology and Biostratigraphy. Marit. Sed., Spec. Publ., 1:315-377.

1980. Microbiostratigraphy of young Cainozoic marine deposits of the Qivituq Peninsula, Baffin Island. Mar. Micropaleontol., 5:153183. 
1985. Late Cenozoic marine deposits East Baffin Island and East Greenland, microbiostratigraphy-correlation-age. In Andrews, J.T. (Ed.), Quaternary Environments: Eastern Canadian Arctic, Baffin Bay, and Western Greenland: Boston (Allen and Unwin), 354-393.

1990. Foraminiferal stratigraphy in the Plio-Pleistocene Kap Kobenhavn Formation, North Greenland. Medd. Groenl., Geosci., 24:132.

Feyling-Hanssen, R.W., Funder, S., and Petersen, K.S., 1982. The Lodin Elv formation: a Plio-Pleistocene occurrence in Greenland. Bull. Geol. Soc. Den., 31:81-106.

Funder, S., Abrahamsen, N., Bennike, O., and Feyling-Hanssen, R.W., 1985. Forested Arctic: evidence from North Greenland. Geology, 13:542-546.

King, C., 1983. Cenozoic micropaleontological biostratigraphy of the North Sea. Inst. Geol. Sci. Rep., 82.

Knudsen, K.L., and Asbjörnsdottir, L., 1991. Plio-Pleistocene foraminiferal stratigraphy and correlation in the Central North Sea. Mar. Geol., 101:113-124.

Matoba, Y., Tomizawa, A., Fukasawa, K., 1990. Neogene and Quaternary sedimentary sequences in the Oga peninsula. Benthos'90 Fieldtrip Guidebook, 2.

McNeil, D.H., 1989. Foraminiferal zonation and biofacies analysis of Cenozoic strata in the Beaufort-Mackenzie Basin of Arctic Canada. Geol. Surv. Can. Pap., 89-1G:203-223.

Nomura, R., 1983a. Cassidulinidae (foraminiferida) from the uppermost Cenozoic of Japan (Pt. 1). Sci. Rep. Tohoku Univ., 53:1-101.

, 1983b. Cassidulinidae (foraminiferida) from the uppermost Cenozoic of Japan (Pt. 2). Sci. Rep. Tohoku Univ., 54:1-93.

Osterman, L.E., 1984. Benthic foraminiferal zonation of a glacial-interglacial transition from Frobisher Bay, Baffin Island, N.W.T., Canada. In Oertli, H.J. (Ed.), Benthos'83, 471-476.
Osterman, L.E., Miller, G.H., and Stravers, J.A., 1985. Middle and Late Foxe glacial events of Southern Baffin Island. In Andrews, J.T. (Ed.), Quaternary Environments: Eastern Canadian Arctic, Baffin Bay and Western Greenland: Boston (Allen and Unwin), 520-545.

Sejrup, H.-P., and Guilbault, J.-P., 1980. Cassidulina reniforme and C. obtuse (foraminifera) taxonomy, distribution and ecology. Sarsia, 65:79-85.

Shipboard Scientific Party, 1995. Site 910. In Myhre, A.M., Thiede, J., Firth, J.V., et al., Proc. ODP, Init. Repts., 151: College Station, TX (Ocean Drilling Program), 221-270.

Todd, R., 1957. Foraminifera from Carter Creek Northeastern Alaska. Geol. Surv. Prof. Pap. U.S., 294-F:260-277.

Vincent, J.S., Morris, W.A., and Occheitti, S., 1984. Glacial and nonglacial sediments of Matuyama paleomagnetic age on Banks Island, Canadian Arctic Archipelago. Geology, 12:139-142.

Volshinova, N.A., 1952. Fossil foraminifera of the U.S.S.R.: Nonionidae, Cassidulinidae, and Chilostomellidae. In Voloshinova, N.A., and Dain, L. (Eds.), VNIGRI, 63. (in Russian)

Weiss, L., 1954. Foraminifera and origin of the Gardiners clay (Pleistocene), Eastern Long Island, New York. Geol. Surv. Prof. Pap. U.S., 254-G:143163.

Willard, D., 1995. Pliocene and Quaternary Pollen assemblages from ODP Sites 910 and 911 (Leg 151), Yermak Plateau, Arctic Ocean. AGU Abstr. S167.

Date of initial receipt: 1 July 1995

Date of acceptance: 12 December 1995

Ms 151SR-107 


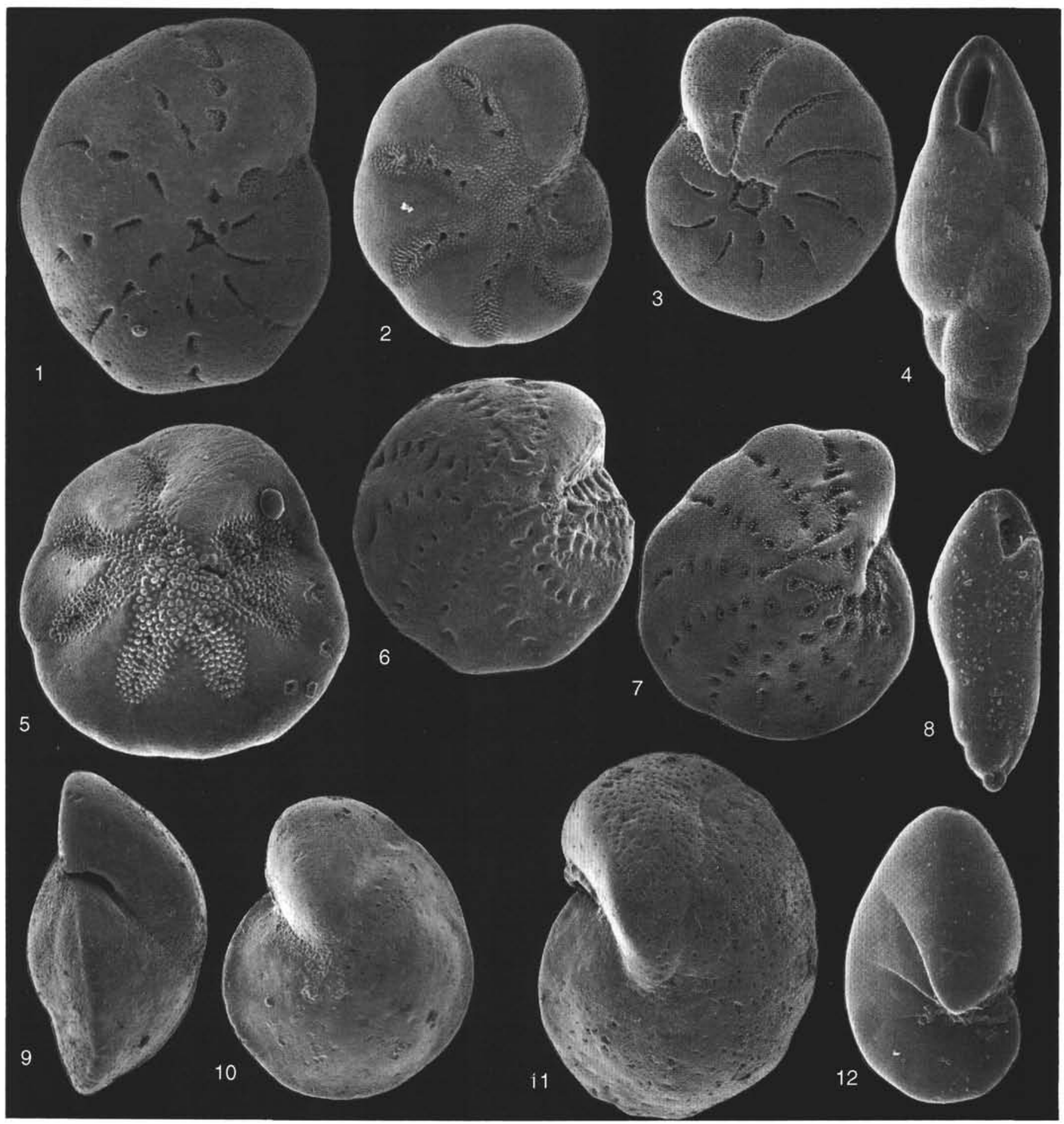

Plate 1. Quaternary and Pliocene foraminifers from Site 910. 1. Elphidicum excavatum, Sample 151-910A-3H-1, 113-117 cm (170X). 2. Elphidium albiumbilicatum, Sample 151-910A-3H-1, 113-117 cm (130×). 3. Elphidicum excavatum forma clavata, Sample 151-910A-3H-1, 113-117 cm (130X). 4. Stainforthia concava, Sample 151-910A-3H-1, 113-117 cm (200X). 5. Buccella arctica, Sample 151-910C-25R-CC (200X). 6. Elphidiella hughesi Sample 151-910D-8RCC (70×). 7. Elphidium groenlandicum, Sample 151-910C-25R-CC (80×). 8. Stainforthia feylingi, Sample 151-910C-1R-1, 3-9 (250×). 9. Cibicides grossa, Sample 151-910C-49R-CC (100X). 10. Cibicides grossa, Sample 151-910C-49R-CC (80X). 11. Cibicides grossa, Sample 151-910C-25R-CC (120X). 12. Nonion labradoricum, Sample 151-910C-1R-1, 3-9 cm (120X). 


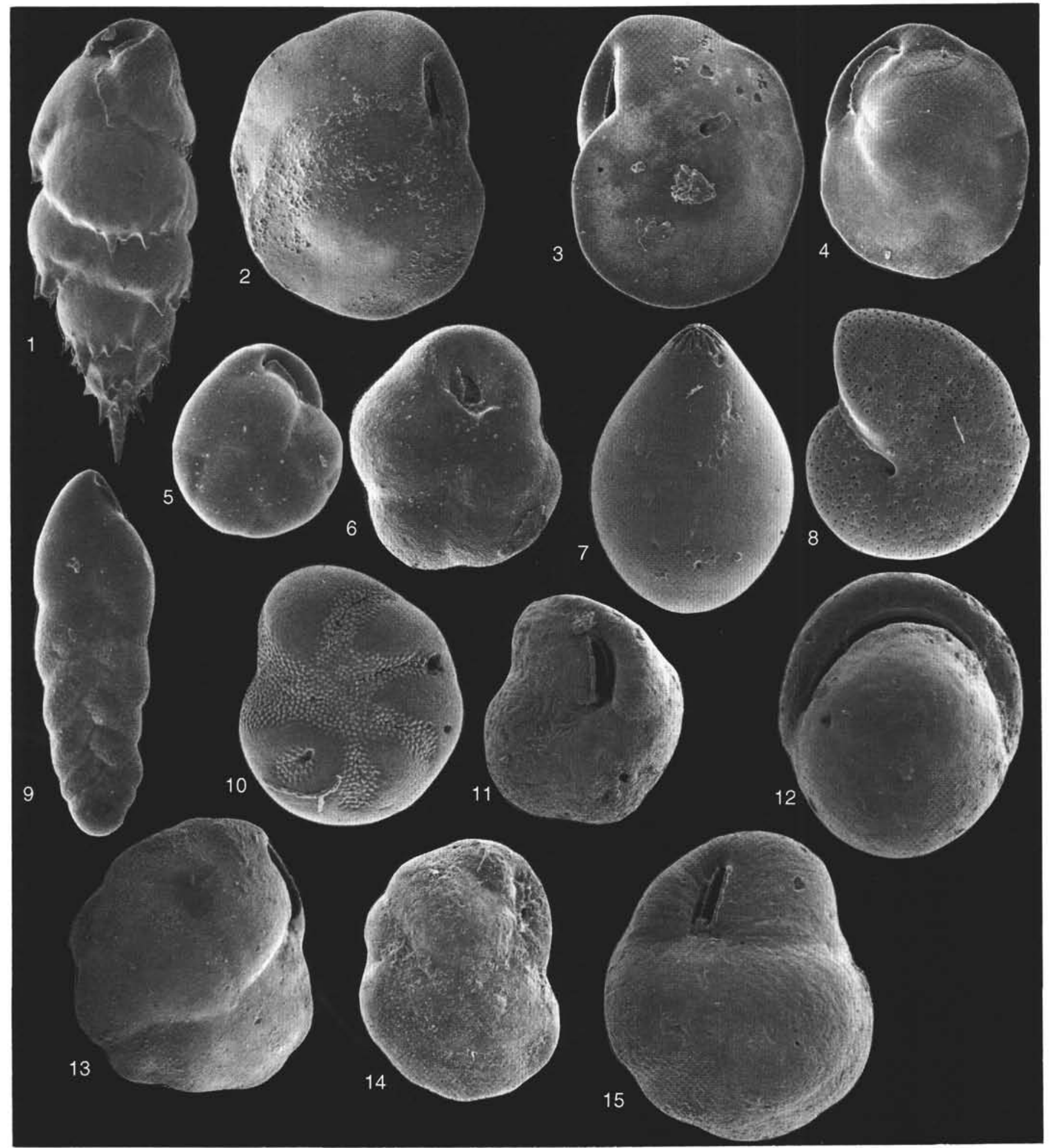

Plate 2. Quaternary and Pliocene foraminifers from Site 910. 1. Bulimina aculeata, Sample 151-910A-3H-1, 113-117 cm (120X). 2. Islandiella norcrossi, Sample 151-910A-3H-1, 113-117cm (150×). 3. Islandiella helenae, Sample 151-910C-1R-1, 3-9 cm (150X). 4. Cassidulina teretis, Sample 151-910A-3H-1, 113$117 \mathrm{~cm}(150 \times)$. 5. Cassidulina reniforme, Sample 151-910A-3H-1, 113-117 cm (170X). 6. Islandiella algida, Sample 151-910A-2H-CC (250X). 7. Glandulina laevigata, Sample 151-910C-25R-CC (120X). 8. Nonion barleeanum, Sample 151-910A-3H-1, 113-117 cm (130X). 9. Brizalina sp., Sample 151-910C-1R-1, $3-9 \mathrm{~cm}(250 \times)$. 10. Nonion matchigaricus, Sample 151-910C-25R-CC (170×). 11. Globocassidulina sp., Sample 151-910C-49R-CC (130×). 12. Pullina bulloides, Sample 151-910C-52R-CC (120×). 13. Cassidulina pliocarinata, Sample 151-910C-51R-CC (170×). 14. Paracassidulina sagminensis, Sample 151910C-51R-CC (170X). 15. Globocassidulina grooviapeture, Sample 151-910C-51R-CC (100×). 